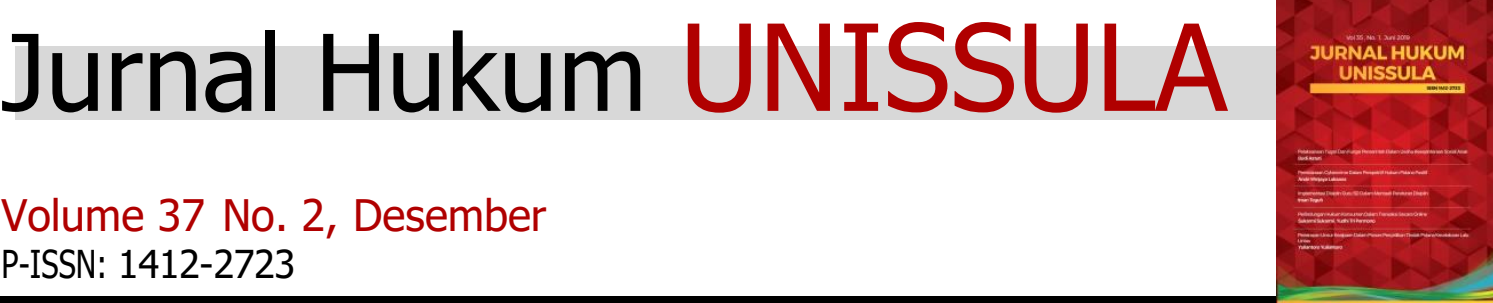

\section{DESAIN IDEAL PEMBENTUKAN OTORITAS INDEPENDEN PERLINDUNGAN DATA PRIBADI DALAM SISTEM KETATANEGARAAN INDONESIA}

\author{
Ahmad Gelora Mahardika \\ Hukum Tata Negara UIN Sayyid Ali Rahmatullah, E-mail: geloradika@gmail.com
}

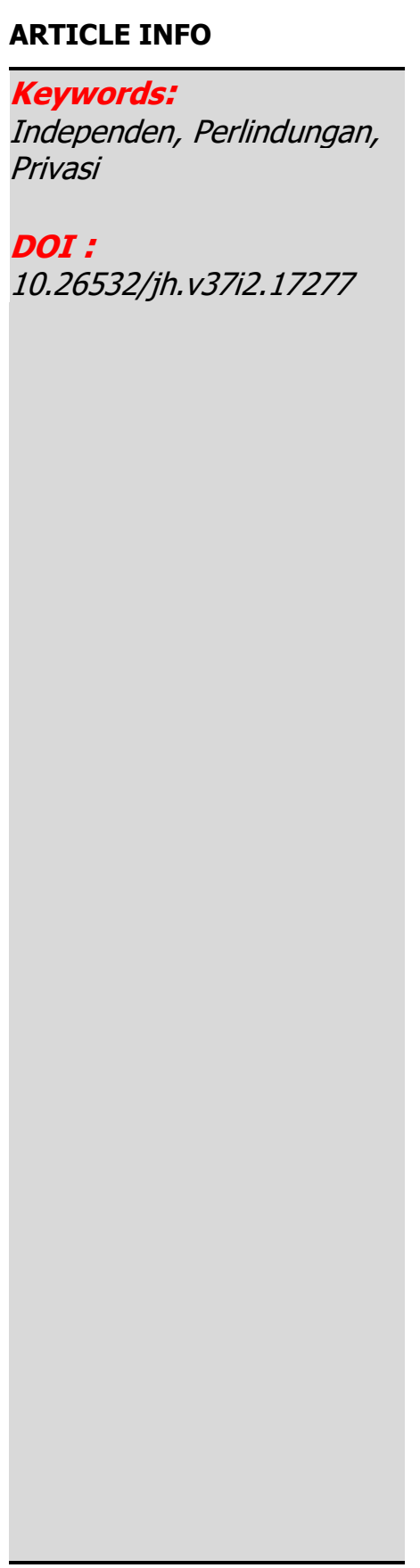

\begin{abstract}
Artikel ini membahas tentang pentingnya pembentukan otoritas independen perlindungan data pribadi dalam sistem ketatanegaraan Indonesia. Hal itu disebabkan, RUU Perlindungan Data Pribadi belum mencantumkan pembentukan otoritas independen. Pengelolaan data pribadi masih berada secara sektoral di kementerian. Padahal pembentukan otoritas independen perlndungan data pribadi sangat penting sebagai upaya kehadiran negara untuk menjamin hak privasi setiap warga negara. Mengacu pada sistem hukum di negara lain, pembentukan otoritas independen mutlak diperlukan, sebagai upaya untuk memastikan independensi lembaga tersebut, dikarenakan tanpa adanya otoritas independen maka akan muncul potensi penyimpangan terhadap penggunaan data pribadi. Maksud dan tujuan dari penulisan artikel ini adalah untuk memastikan urgensi pembentukan lembaga inpenden perlindungan data pribadi dalam sistem hukum Indonesia. Metode penelitian yang digunakan dalam artikel ini adalah yuridis normatif. Signifikansi dalam artikel ini adalah diharapkan memberikan landasan akademik bagi Pemerintah untuk menambahkan otoritas independen perlindungan data pribadi dalam RUU Perlindungan Data Pribadi. Kesimpulan dalam artikel ini adalah perlunya dibentuk otoritas independen perlindungan data pribadi dalam sistem ketatanegaraan Indonesia.
\end{abstract}

This article discusses the importance of establishing an independent authority for personal data protection in the Indonesian constitutional system. This is because the Personal Data Protection Bill does not include the establishment of an independent authority. The management of personal data is still on a sectoral basis at the ministry. In fact, the establishment of an independent authority for the protection of personal data is very important as an effort to ensure the presence of the state to guarantee the privacy rights of every citizen. Referring to the legal system in other countries, the establishment of an independent authority is absolutely necessary, as an effort to ensure the independence of the institution, because without an independent authority there will be potential for deviations from data deviations. protection of personal data in the Indonesian legal system. The research method used in this article is normative juridical. The significance of this article is that it is expected to provide an academic basis for the Government to add an independent authority for personal data protection in the 


\section{A. PENDAHULUAN}

Pasal 28G UUD NRI 1945 menyatakan bahwa setiap orang berhak atas perlindungan diri pribadi, keluarga, kehormatan, martabat, dan harta benda yang di bawah kekuasaannya, serta berhak atas rasa aman dan perlindungan dari ancaman ketakutan untuk berbuat atau tidak berbuat sesuatu yang merupakan hak asasi. Ketentuan tersebut memang tidak secara eksplisit menyebutkan terkait hak privasi, akan tetapi norma dalam Pasal tersebut menjelaskan posisi negara yang secara konstitusional mempunyai kewajiban untuk menjaga privasi setiap warga negara melalui perlindungan data pribadi.

Dalam konteks era revolusi industri 4.0, inovasi dan teknologi yang berkembang mempunyai kapabilitas untuk melakukan penyimpanan serta analisis data sebagai upaya untuk memudahkan aktivitas manusia. Perubahan tersebut berdampak terhadap segala aktivitas manusia yang tak lepas dari teknologi, baik itu dalam aspek penyelenggaraan e-commerce untuk sektor perdagangan, mobile-bangking untuk sektor perbankan, online education untuk bidang pendidikan, e-government untuk segala bentuk pelayanan pemerintah berbasis daring, social media (facebook, twitter, instagram, tik-tok) untuk interaksi, search engine (google), google maps untuk pencarian informasi, serta segala bentuk penyimpanan data otomatis tekoneksi dari telepon genggam melalui metode cloud.

Segala aktivitas tersebut diatas membutuhkan verifikasi identitas yang dilakukan oleh pengendali atau prosessor. Hal itu sebagai upaya untuk memastikan orang yang melakukan aktivitas elektronik tersebut bukan bot (robot), melainkan orang (person) yang dapat dipertanggungjawabkan secara hukum. Kondisi tersebutlah yang kemudian menjadikan alasan bagi pengendali untuk memastikan agar setiap pengguna yang hendak memanfaatkan layananannya untuk memasukkan data pribadi mereka seperti nama, alamat, tempat tanggal lahir, nomor induk kependudukan, kartu keluarga, serta sejumlah identitas lainnya yang pada hakikatnya merupakan informasi privasi.

Namun menjadi persoalan adalah ketika identitas pribadi yang selayaknya dijaga erat oleh pengendali tiba-tiba mengalami kebocoran dan berpotensi menimbulkan tindakan penipuan serta penyalahgunaan. Kondisi itulah yang menjadi salah satu landasan sosiologis bagi pembentuk undangundang untuk menerbitkan pengaturan terkait perlindungan data pribadi.

Perlindungan data pribadi berhubungan dengan konsep privasi. Konsep privasi sendiri adalah gagasan untuk menjaga integritas dan martabat pribadi. ${ }^{1}$ Hak pribadi mempunyai keterkaitan dengan hak untuk menjaga informasi rahasia terhadap orang lain. Hal itu ditegaskan oleh Anita Allen yang membagi hak privasi menjadi tiga macam, "Informational privacy, bodily privacy, and decisional privacy are the three types of privacy

1 Wahyudi Djafar and Asep Komarudin, Perlindungan Hak Atas Privasi Di Internet-Beberapa Penjelasan Kunci, Elsam, Jakarta, 2014 
protected by privacy rights. Informational privacy refers to the desire for secrecy, anonymity, and confidentiality, and is most commonly understood as the right to keep personal information private from others. ${ }^{22}$ Pendapat tersebut juga disepakati Westin yang menyatakan bahwa " $A$ person's right to privacy is defined as the ability to "control, amend, manage, and remove information about him or her, as well as determine when, how, and to what degree this information can be accessible by others." ${ }^{3}$ Oleh karena itulah, hak privasi dapat dimaknai sebagai kekuasaan seseorang untuk membagikan informasi kepada siapapun yang mereka kehendaki serta untuk apa informasi tersebut digunakan.

Disisi lain, kebocoran informasi merupakan pelanggaran hak privasi, karena hak privasi mencakup hak untuk mengontrol informasi terkait dirinya apakah diberikan ataukah tidak (the right to control certain kinds of information about oneself). ${ }^{4}$ Sementara itu, pengaturan terkait hak privasi terkait data pribadi dalam sistem hukum Indonesia belum terkodifikasi secara optimal atau masih tercecer pada beberapa regulasi sebagai contoh adalah UU No. 36 Tahun 2009 tentang Kesehatan yang didalamnya terdapat norma terkait kerahasiaan kondisi pribadi pasien, dan UU No. 10 Tahun 1998 tentang Perbankan yang mengatur terkait data pribadi mengenai nasabah penyimpan dan simpanannya. Kondisi ini menyebabkan perlindungan data pribadi masih parsial serta sektoral yang berdampak terhadap potensi adanya pelanggaran hak asasi manusia manakala terjadi kebocoran informasi. Berdasarkan sejumlah hal tersebut diatas, pembahasan rancangan undang-undang yang secara khusus menangangi perlindungan data pribadi menjadi salah satu hal yang bersifat urgen.

Namun, rancangan undang-undang perlindungan data pribadi yang saat ini dibahas oleh Pemerintah dan DPR masih mempunyai celah yang berpotensi memunculkan pelanggaran. Hal itu disebabkan, RUU Perlindungan Data Pribadi belum mengatur terkait pembentukan otoritas independen perlindungan data pribadi. Dalam draft rancangan undangundang, otoritas terkait perlindungan data pribadi diberikan kepada Pemerintah melalui Menteri Komunikasi dan Informatika. Padahal dalam draft tersebut, Kementerian dikategorikan sebagai badan publik yang menjadi salah satu obyek dalam perlindungan data pribadi, oleh karena itulah pemberian otoritas kewenangan kepada Menteri Komunikasi dan Informatika berpotensi menciptakan kompleksitas persoalan baru. Persoalan tersebut berkaitan dengan independensi Menkominfo dalam perlindungan data pribadi. Berdasarkan asas hukum nemo judex in causa sua, yang bermakna tidak seorangpun selayaknya mengawasi dirinya sendiri, pemberian kewenangan pengelolaan perlindungan data pribadi kepada Menteri berpotensi melanggar asas hukum tersebut.

Berdasarkan hal tersebut, kehadiran otoritas independen menjadi

2 Michele L. Tyler, Blowing Smoke: Do Smokers Have a Right? Limiting the Privacy Rights of Cigarette Smokers, Georgetown Law Journal, Vol.86, No.3, 1998, hal.783

3 Tadas Limba and Aurimas Šidlauskas, Secure Personal Data Administration in the Social Networks: The Case of Voluntary Sharing of Personal Data on the Facebook, Entrepreneurship and Sustainability Issues, Vol.5, No.3, 2018, hal.528-41

4 Scott A. Anderson, Privacy without the Right to Privacy, Monist, Vol.91, No.1, 2008, hal.81107 
sesuatu hal yang vital dalam sistem ketatanegaraan Indonesia. Keberadaan lembaga independen akan memastikan bahwa proses ombudsman, auditor, serta penegakan hukum yang terkait perlindungan data pribadi akan dilakukan secara mandiri. Hal tersebut penting, karena objek dari undangundang perlindungan data pribadi tidak hanya orang (person) melainkan badan hukum publik antara lain kekuasaan diranah eksekutif, legislatif maupun yudikatif. Pemberian otoritas perlindungan data pribadi kepada lembaga independen, akan memastikan imparsialitas penegakan hukum terkait perlindungan data pribadi.

Selain itu, konsep otoritas independen pada hakikatnya bukanlah sesuatu hal yang baru. Berdasarkan sejumlah kesepakatan internasional antara lain "UN Guidelines for The Regulation of Computerized Personal Data Files 1990" yang merupakan kesepakatan PBB terkait Data Pribadi, disebutkan dalam bab pengawasan terkait pentingnya otoritas independen. "...independence vis-avis persons or agencies responsible for processing and establishing data, and technical competence". Terlihat dalam bagian tersebut, pembentukan otoritas independen merupakan salah satu prinsip dasar dalam pembentukan regulasi yang mengatur perlindungan data pribadi.

Namun, salah satu persoalannya adalah bagaimanakah desain ideal pembentukan lembaga otoritas independen perlindungan data pribadi dalam sistem ketatanegaraan Indonesia. Hal ini penting untuk dikaji, dikarenakan lembaga negara tersebut harus dapat dipastikan independensinya karena objek dari Undang-Undang Perlindungan Data Pribadi salah satunya adalah badan publik.

Sejumlah penelitian terdahulu terkait otritas independen perlindungan data pribadi telah pada hakikatnya sudah pernah dilakukan. Penelitian pertama dilakukan oleh Nina Gumzej, dalam artikelnya yang berjudul "Selected Aspects of Proposed New EU General Data Protection Legal Framework And The Croatian Perspective". Artikel tersebut menggambarkan peran penting otoritas perlindungan data pribadi di negaranegara Uni Eropa. Artikel tersebut juga menggambarkan pentingnya lembaga tersebut untuk independen. Artikel kedua adalah yang ditulis oleh Andras Jori yang bejudul "Shaping vs Applying Data Protection Law: Two Core Functions Of Data Protection Authorities". Senada dengan Gumzej, Jori menggambarkan pentingnya pembentukan otoritas independen perlindungan data pribadi. Menurut Jori, tanpa adanya independensi maka akan berpotensi munculnya penyelewengan. Artikel ketiga adalah yang ditulis oleh Marta-Claudia Cliza, Negura Spataru, dan Cristiana Laura yang berjudul "The General Data Protection Regulation: What Does The Public Authorities And Bodies Need To Know And To Do? The Rise Of The Data Protection Officer". Artikel tersebut menggambarkan pentingnya independensi bagi pegawai yang menangani persoalan perlindungan data prbadi.

Berdasarkan latar belakang tersebut diatas, artikel ini hendak menjawab dua pertanyaan yaitu apakah urgensi pembentukan otoritas independen Undang-Undang Perlindungan Data Pribadi, serta Bagaimanakah desain ideal pembentukan Otoritas Independen Dalam Undang-Undang 
Perlindungan Data Pribadi dalam Sistem Ketatanegaraan Indonesia ?

\section{B. METODE PENELITIAN}

Penelitian akan dilakukan melalui yuridis normatif, yaitu mengkaji dan menganalisis peraturan perundang-undangan atau hukum lain yang berkaitan dengan desain ideal pembentukan otoritas perlindungan data pribadi. Penelitian hukum ini dilakukan melalui pendekatan regulasi (statutory approach). ${ }^{5}$ Pendekatan regulasi dilakukan dengan melakukan kajian secara mendalam terhadap sejumlah peraturan perundang-undangan yang terkait dengan tema penulisan.

Penelitian hukum normatif ini memanfaatkan jenis data sekunder atau bahan yang didapatkan melalui studi literatur, sehingga metode pengumpulan data dilaksanakan dengan mencari pustaka yang relevan, baik melalui perpustakaan maupun pusat data jurnal daring. Pengumpulan data sekunder yang digunakan dalam penelitian ini difokuskan pada: (a) bahan hukum primer, berupa peraturan perundang-undangan baik di tingkat nasional ataupun internasional yang terkait dengan tema penelitian antara lain UUD NRI 1945 dan sejumlah peraturan internasional dan (b) bahan hukum sekunder, berupa buku referensi dan jurnal yang terkait dengan tema penelitian yaitu lembaga independen perlindungan data pribadi.

\section{TENTANG LEMBAGA NEGARA INDEPENDEN}

Istilah independen dalam bahasa Inggris adalah independent yaitu "not governed by another, not requiring or relying on something or somebody else, not easily influenced". Black's Law Dictionary menyebutkan independen sebagai "not dependent; not subject to control, restriction, modification, or limitation from a given outside source" (tidak tergantung, tidak tunduk pada kontrol, pembatasan, modifikasi atau keterbatasan sumber daya yang disediakan di luar). Jadi dapat dipahami bahwa yang dimaksud Independensi merupakan suatu keadaan atau situasi dimana seseorang tidak terikat dengan siapapun atau pihak manapun. Artinya keberadaannya adalah mandiri. Tidak membawa kepentingan pihak tertentu atau organisasi tertentu serta bebas dari campur tangan pihak tertentu. ${ }^{6}$

Lembaga negara independen merupakan istilah yang paling umum digunakan oleh ahli dan sarjana hukum tata negara, walaupun pada kenyataannya ada yang berpendapat bahwa istilah "lembaga negara penunjang" atau "lembaga negara independen" $M$. Laica Marzuki kembali menghindari kerancuan dengan lembaga lain yang berkedudukan di bawah lembaga negara konstitusional dengan istilah state auxiliary institutions alihalih "lembaga negara independen" untuk menghindari kerancuan dengan lembaga lain yang berkedudukan di bawah lembaga negara konstitusional. ${ }^{7}$

5 Johni Ibrahim, Teori Dan Metodologi Penelitian Hukum Normatif, Bayumedia Publishing, Malang, 2007

6 Metia Winati Muchda, Maryati Bachtiar, and Dasrol, Pengalihan Tugas Pengaturan Dan Pengawasan Perbankan Dari Bank Indonesia Kepada Otoritas Jasa Keuangan Berdasarkan Undang-Undang Nomor 21 Tahun 2011 Tentang Otoritas Jasa Keuangan, JURNAL EKONOM Vol.22, No.2, 2014, hal.1-17

7 Rizki Ramadani, Lembaga Negara Independen Di Indonesia Dalam Perspektif Konsep Independent Regulatory Agencies, Jurnal Hukum Ius Quia Iustum, Vol.27, No.1, 2020 
Kedudukan lembaga-lembaga ini tidak berada dalam ranah cabang kekuasaan eksekutif, legislatif, maupun yudikatif. Akan tetapi, sejumlah lembaga tersebut tidak juga dapat diperlakukan sebagaimana organisasi swasta ataupun lembaga non-pemerintah (organisasi non-pemerintah) atau NGO (non-governmentm alorganization) meksipun mempunyai kemiripan dengan NGO karena sumber pendanaan yang berasal dari publik, serta bertujuan untuk kepentingan publik, membuatnya tidak dapat disebut sebagai NGO dalam arti sebenarnya.

Sebagian ahli secara konsisten mengelompokkan lembaga independen semacam ini dalam ranah kekuasaan eksekutif, walaupun ada beberapa yang menempatkannya secara tersendiri sebagai cabang keempat dalam kekuasaan pemerintahan, seperti dinyatakan oleh Yves Meny dan Andrew Knapp berikut ini. " Regulatory and oversight bodies are a new sort of autonomous administration that has grown in popularity in the United States (where it is frequently described to as the government's "headless fourth branch"). It manifests itself in the form of Independent Regulatory Commissions (IRCS)".

Secara teoritis, lembaga negara independen diawali dari keinginan negara untuk menciptakan lembaga negara baru yang pengisian anggotanya diambil dari unsur non-negara, diberi otoritas, serta dibiayai oleh negara tanpa harus menjadi pegawai negara. Wacana lembaga negara independen pada hakikatnya berasal dari hasrat negara yang sebelumnya kuat ketika berhadapan dengan masyarakat, rela untuk memberikan kesempatan kepada masyarakat untuk mengawasi. Jadi, meskipun negara masih tetap kuat, ia diawasi oleh masyarakat sehingga tercipta akuntabilitas vertikal dan akuntabilitas horizontal. ${ }^{9}$

Perkembangan konsep kelembagaan Negara dalam era demokrasi modern telah mendorong terbentuknya lembaga-lembaga negara baru yang memiliki tugas dan fungsi khusus sesuai dengan latar belakang pembentukannya. Sejumlah ahli HTN Indonesia masih belum mempunyai kesepakatan redaksi untuk menyebut lembaga ini, sejumlah pakar menyebut lembaga negara yang membantu, lembaga negara yang menunjang, lembaga negara pelayan, lembaga negara independen dan lembaga negara mandiri. Pembentukan lembaga tersebut dikarenakan adanya tujuan yang ingin dicapai dalam sutu negara dinilai tidak dapat dicapai hanya dengan lembaga utama saja (Main State's Organ). Maka, dibentuklah lembagalembaga pembantu (Auxiliary State's Organ), yang mempunyai fungsi melayani. ${ }^{10}$

Berkaitan dengan lembaga independen yang memiliki fungsi pada cabang kekuasaan eksekutif dan yudikatif, Undang-Undang Dasar Negara Republik Indonesia Tahun 1945 telah memberikan ruang bagi terciptanya institusi lain yang fungsinya ada relasi dengan kekuasaan yudikatif sepanjang diatur dalam regulasi. Ketentuan itu memberikan legalitas pada

8 Eki Furqon, Kedudukan Lembaga Negara Independen Berfungsi Quasi Peradilan Dalam Sistem Ketatanegaraan Indonesia, Nurani Hukum, Vol.3, No.1 2020, hal.77

9 Suparto, Pemisahan Kekuasaan, Konstitusi Dan Kekuasaan Kehakiman Yang Independen Menurut Islam, Jurnal Selat, Vol.4, No.1, 2016, hal.121

10 Hardiyanto Djanggih and Yusuf Saefudin, De Jure De Jure, Jurnal Penelitian Hukum, Vol.17, No.3, 2017, hal.413-25 
lembaga-lembaga negara baru yang bersifatpenunjang untuk dapat memiliki sebagian wewenang dari cabang kekuasaan yudikatif. ${ }^{11}$ Semenjak reformasi yang ditandai dengan amandemen Undang- Undang Dasar Negara Republik Indonesia Tahun 1945, kemungkinan untuk terciptanya lembaga-lembaga negara baru yang bersifat independen dan berfungsi quasi peradilan sangat terbuka. Pembentukan lembaga-lembaga independen ini dianggap menjadi jawaban untuk melakukan kontrol terhadap kekuasaan pemerintah, sekaligus juga menjadi momentum peninjauan kembali desain kelembagaan negara.

Konsep independensi dalam suatu lembaga mempunyai variasi yang berbeda-beda. Menurut Metia Winadi, independensi suatu lembaga dapat dibagi menjadi beberapa kategori: ${ }^{12}$

Pertama, independensi institusional dipahami juga sebagai political atau goal independence, karena kemandirian mempunyai makna bahwa status lembaga tersebut tidak terikat dengan kekuasaan eksekutif atau pemerintah, bebas dari pengaruh parlemen, serta bebas dari lembaga politik dan atau pemerintah

Kedua, independensi fungsional atau dapat diartikan dengan instrument independence yaitu lembaga bebas menentukan metode ataupun implementasi dari media kebijakan yang dianggap penting untuk mencapai visi dan misinya

Ketiga, independensi organisasional sebagai upaya pencegahan intervensi politik serta menjaga integritas yaitu berhubungan dengan personalia.

Selanjutnya, Zainal Arifin Mochtar dan Iwan Satriawan senada dengan Winaldi, sifat independen dapat digambarkan dari sejumlah hal: ${ }^{13}$

1. Kepemimpinan lembaga kolektif kolegial, dalam artian pimpinan bukan tunggal. Hal ini penting agar pengambilan keputusan tidak dilakukan secara sepihak dan semena-mena;

2. Leadership tidak dikooptasi dari partai politik; dan

3. Durasi jabatan pimpinan tidak habis secara bersamaan, namun dilakukan secara shifting.

\section{Tentang Proteksi Data Pribadi}

Suatu data dapat disebut data apabila digunakan untuk mengidentifikasi orang tertentu, yaitu pemilik data. ${ }^{19}$ Mengacu pada Pasal 4 (1) GDPR disebutkan bahwa yang dapat dikategorikan sebagai

11 Ramadani, Lembaga Negara Independen Di Indonesia Dalam Perspektif Konsep Independent Regulatory Agencies.

12 Muchda, Bachtiar, and Dasrol, Pengalihan Tugas Pengaturan Dan Pengawasan Perbankan Dari Bank Indonesia Kepada Otoritas Jasa Keuangan Berdasarkan Undang-Undang Nomor 21 Tahun 2011 Tentang Otoritas Jasa Keuangan.

13 Zainal Arifin Mochtar, Lembaga Negara Independen: Dinamika Perkembangan Dan Urgensi Penataannya Kembali Pasca Amandemen Konstitusi, PT Raja Grafindo Persada, Jakarta, 2016

14 European Union Agency for Fundamental Rights and Council of Europe, Handbook on European Data Protection Law, Belgium, 2014 
data pribadi adalah: ${ }^{15}$

"any data relating to an identified or identifiable natural person ('data subject'); an identifiable natural person is one who can be identified, directly or indirectly, in particular by reference to an identifier such as a name, an identification number, location data, an online identifier, or one or more factors specific to that natural person's physical, physiological, genetic, mental, economic, cultural, or social identity."

Terlihat dari definisi tersebut diatas, data pribadi dapat dimaknai sebagai data atau informasi yang mampu mengidentifikasi orang secara spesifik. Oleh karena itulah, data pribadi seseorang merupakan sesuatu yang harus dilindungi kerahasiannya karena kebocoran data pribadi berpengaruh terhadap kebebasan seseorang untuk berekspresi serta rentan terhadap penyalahgunaan data pribadinya oleh orang lain. ${ }^{16}$ Kekhawatiran lainnya yaitu bilamana informasi yang berhubungan dengan hal-hal pribadi berpotensi diketahui secara luas, ada ketakutan bahwa setiap aktivitas yang dilakukan akan diketahui dan diawasi pihak asing.

Oleh karena itulah data pribadi mempunyai keterkaitan erat dengan hak privasi. Mengacu pada pendapat Pfisterer, hak privasi adalah: ${ }^{17}$

"That right applies to any information about a person who can be identified or identified. This remark appears to imply that nonindividuals, such as corporations, partnerships, associations, and other legal entities, cannot benefit from the right to privacy as a matter of principle."

Selain itu hak privasi merupakan salah satu hak asasi manusia yang bersifat fundamental yang bahkan menurut Diggelman merupakan hak yang melekat sebelum muncul konstitusi, ${ }^{18}$

"The 'right to security' was perceived as a worldwide common liberty before it was remembered for any state constitution."

Berdasarkan hal tersebut diatas, hak atas perlindungan data pribadi merupakan bagian dari hak privasi yang selayaknya dilindungi oleh negara. Namun perlindungan privasi tidak berarti tanpa batasan. Dalam hal tertentu terdapat informasi yang secara luas disepakati sebagai informasi pribadi yang tidak dilindungi bahkan atas nama hukum berhak disimpangi, misalnya informasi mengeni jumlah rekening yang dimiliki, nama ibu, maupun tanda lahir yang melekat pada tubuh.

Pada umumnya masyarakat menganggap informasi tersebut

15 Michèle Finck and Frank Pallas, They Who Must Not Be Identified-Distinguishing Personal from Non-Personal Data under the GDPR, International Data Privacy Law Vol.10, No.1, 2020, hal.11-36,

16 Siti Yuniarti, Perlindungan Hukum Data Pribadi Di Indonesia, Business Economic, Communication, and Social Sciences (BECOSS) Journal, Vol.1, No.1, 2019, hal.147-54

17 Valentin M. Pfisterer, The Right to Privacy-a Fundamental Right in Search of Its Identity: Uncovering the CJEU's Flawed Concept of the Right to Privacy, German Law Journal 20, no. 5,2019 , hal.722-33

18 Oliver Diggelmann and Maria Nicole Cleis, How the Right to Privacy Became a Human Right, Human Rights Law Review, Vol.14, No.3, 2014, hal.441-58 
merupakan hal yang sifatnya pribadi. Namun ketika terjadi kondisi khusus yang mengharuskan terjadi pengungkapan data-data tersebut maka pemilik informasi tidak dapat menolak untuk memberitahukan atau mengemukakan informasi tersebut dengan dalih menyangkut privasi. Selama privasi tersebut terkait dengan kepentingan publik dan digunakan dengan terbatas dilindungi undang-undang, maka perlindungan privasi dapat terabaikan. Akan tetapi untuk menghindari terjadinya penyalahgunaan terkait informasi tersebut, maka selayaknya pengaturannya dilakukan oleh lembaga independen.

\section{Urgensi Pembentukan Otoritas Independen Perlindungan Data Pribadi}

Salah satu persoalan dalam rancangan undang-undang perlindungan data pribadi adalah ketiadaan otoritas pengawas independen perlindungan data pribadi. Padahal otoritas independen diperlukan sebagai upaya untuk memastikan tidak ada penyalahgunaan data pribadi. Hal ini penting, karena mengacu pada Pasal 2 RUU Perlindungan Data Pribadi disebutkan bahwa objek dari RUU Perlindungan Data Pribadi adalah setiap orang, badan publik, dan organisasi/institusi. Disisi lain dalam draft RUU PDP, otoritas sebagaimana yang dimaksud dilakukan oleh Pemerintah yang tak lain termasuk dalam kategori badan publik sebagaimana yang diatur dalam ketentuan umum RUU Perlindungan Data Pribadi.

Pembentukan otoritas independen pada hakikatnya merupakan amanat dari sejumlah kesepakatan internasional terkait perlindungan data pribadi, antara lain:

a. UN Guidelines for The Regulation of Computerized Personal Data Files 1990

Regulasi ini pada dasarnya merupakan rujukan bagi setiap negara yang hendak mengatur terkait perlindungan data pribadi. Dalam regulasi tersebut, disebutkan terkait prinsip-prinsip dasar minimal dalam pembentukan undang-undang terkait perlindungan data pribadi disuatu negara, salah satunya adalah

"The law of every country shall designate the authority which, in accordance with its domestic legal system, is to be responsible for supervising observance of the principles set forth above. This authority shall offer guarantees of impartiality, independence vis-avis persons or agencies responsible for processing and establishing data, and technical competence. In the event of violation of the provisions of the national law implementing the aforementioned principles, criminal or other penalties should be envisaged together with the appropriate individual remedies."

Terlihat diatas, salah satu prinsip dasar pembentukan undangundang perlindungan data pribadi menurut UN Guidelines for The Regulation of Computerized Personal Data Files 1990 adalah dibentuknya otoritas yang imparsial serta independen. 
b. Euorepean Modernized Convention for The Protection of Individual with Regard to The Processing of Personal Data 1981 (Convention 108)

Convention 108 merupakan kesepakatan bersama negara uni eropa terkait standar minimal regulasi perlindungan data pribadi. Berdasarkan Convention 108 disebutkan bahwa tujuan dari disepakatinya aturan ini adalah:

1) Each Party shall select one or more authorities, whose names and addresses it shall disclose to the Council of Europe's Secretary General;

2) Each Party that has designated more than one authority must specify the competence of each authority in the communication referred to in the preceding subparagraph..

Terlihat dari salah satu bunyi pasal dalam Convention 108 diatas, pada hakikatnya standart minimal pengaturan perlindungan data pribadi adalah pembentukan satu atau lebih otoritas yang secara khusus menangangi persoalan perlindungan data.

c. APEC Privacy Framework 2015

APEC Privacy Framework 2015 pada hakikatnya merupakan kesepakatan bersama negara-negara anggota APEC terkait perlindungan data pribadi berkaitan dengan aktivitas ekonomi suatu negara. Berdasarkan APEC Privacy Framework disebutkan bahwa

"Cooperation to promote both effective information and electronic commerce and innovation is a major aspect of APEC economies' efforts to boost consumer confidence and assure the expansion of electronic commerce and innovation. privacy protection and the free flow of information in the Asia Pacific region, while respecting domestic laws and regulations, worldwide frameworks for data privacy protection and information security in the Asia Pacific area."

Selain itu dalam salah satu pasal lainnya disebutkan bahwa:

"A Privacy Enforcement Authority is a public body that is responsible for enforcing an APEC economy's Privacy Law. It will have powers to conduct investigations and/or pursue enforcement proceedings. An economy may have more than one Privacy Enforcement Authority."

Terlihat berdasarkan penjelasan diatas, APEC Privacy Framework 2015 telah menyepakati terkait pembentukan otoritas perlindungan data pribadi, akan tetapi desain pembentukan otoritas tersebut didasarkan pada sistem ketatanegaraan masing-masing negara anggota APEC.

d. Euoropean Union General Data Protection Regulation (GDPR)

GDPR merupakan regulasi terkait perlindungan data pribadi yang disepakati oleh negara-negara Uni Eropa serta menjadi rujukan bagi negara-negara lain dalam membentuk regulasi yang mengatur perlindungan data pribadi. Berdasarkan Pasal 117 European Union GDPR disebutkan bahwa: 
"The formation of supervisory authorities in Member States, enabled to execute their jobs and exercise their powers completely independently, is a critical component of protecting natural persons when their personal data is processed. To reflect their constitutional, organizational, and administrative structures, Member States should be permitted to establish multiple supervisory authorities."

Terlihat berdasarkan ketentuan yang tercantum dalam GDPR diatas, pembentukan otoritas independen merupakan salah satu komponen penting dalam undang-undang perlindungan data pribadi. Bahkan, GDPR memberikan rekomendasi agar pembentukan otoritas independen lebih dari satu institusi.

Selain itu, menurut Tivadar Huttl, terdapat sejumlah pandangan yang mengisyaratkan pentingnya otoritas independen dalam perlindungan data pribadi. Huttl membaginya kedalam tiga macam pandangan:

a. The European Commission's view

Menurut pandangan Komisi Eropa otoritas independen selayaknya bebas dari pengaruh apapun, konsep komisi Eropa dikenal dengan "complete independence".

"The supervisory authority should be free of all forms of influence, whether it comes from within or outside the administration. As a result, the member state's regulation should make it impossible for supervisory authorities' decisions and execution to be influenced from the outside. The word 'total independence' not only implies that there is no dependency of any kind (on anyone), but also that there is no dependence in any kind."

b. The German View

Berbeda dengan The European Commision View, menurut The German View independensi otoritas perlindungan data pribadi tidak secara keseluruhan terpisah dengan kekuasaan lainnya. Independensi terbatas pada fungsinya semata yang bersifat independen.

"The independence of authorities includes a functional independence, which indicates that the authorities must be isolated completely and exclusively from the organizations that they supervise, and Community law mandates that any influence in this direction be avoided."

c. The Advocate General Opinion

Berbeda dengan The European Commission's view dan The German View, menurut The Advocata General Opinion, independensi lembaga dapat diukur melalui proses litigasi yang adil, independensi tidak dapat diukur dengan keterkaitan otoritas independen tersebut dengan kekuasaan lainnya.

"The existence of supervisory authorities is one of the directive's tools for striking a fair balance between the free movement of personal data and the protection of the right to a private life; however, the supervisory authorities' independence has nothing to do with the authorities' scrutiny, or the lack thereof." 


\section{Otoritas Independen Perlindungan Data Pribadi di Sejumlah Negara}

Sebagai gambaran untuk melihat desain otoritas independen terkait perlindungan data pribadi, penulis akan melakukan studi komparasi dengan penerapan otoritas independen perlindungan data pribadi disejumlah negara. Negara yang dilakukan studi komparasi adalah Singapura dan Korea Selatan. Pemilihan kedua negara tersebut didasarkan pada fakta bahwa Korea Selatan merupakan salah satu negara di Asia selain Jepang yang dianggap memenuhi standart (adequacy) kesetaraan hukum perlindungan data sebagaimana Pasal 43 GDPR. Sementara itu, Singapura dianggap sebagai negara di Asia Tenggara yang paling baik dalam pengelolaan data pribadi.

a. Korea Selatan

Pengaturan data pribadi di Korea Selatan diatur dalam Personal Information Protection Act 2011 (PIPA). Pada Pasal 7 PIPA disebutkan bahwa terkait pengaturan data pribadi dibentuk lembaga khusus yang disebut Personal Information Protection Commission (PIPC). Anggota PIPC terdiri dari lima belas orang komisioner yang dipilih oleh Presiden. Selain itu PIPC juga mempunyai sifat independen, hal tersebut dapat dibuktikan mengacu pada Pasal 7 ayat (1) PIPA yang berbunyi:

"The Personal Information Protection Commission (hereinafter referred to as the "Commission") shall be established under the Presidential Office to deliberate and resolve the matters regarding data protection. The Commission shall independently conduct the functions belonging to its authority."

Fungsi dari PIPC dalam sistem ketatanegaraan Korea Selatan adalah mengkaji atau mempertimbangkan serta menyelesaikan:

1) pelaksanaan perencanaan dasar dan rencana implementasi yang tercantum dalam PIPA Korea Selatan;

2) terkait revitalisasi policy, sistem dan regulasi yang berkaitan dengan perlindungan informasi;

3) problematika koordinasi posisi yang terdapat dalam institusi negara terkait pemrosesan informasi pribadi; dan

4) masalah terkait pemahaman dan operasi penegakan hukum serta regulasi terkait perlindungan information pribadi;

5) sejumlah hal lain yang berkaitan dengan pelaksanaan pasal-pasal di dalam PIPA Korea Selatan

b. Singapura

Pengaturan terkait perlindungan data pribadi di Singapura tercantum dalam The Personal Data Protection Act No. 26 of 2012 Singapore (PDPA). Pada pasal 5 diatur terkait badan yang khusus menangangi perlindungan data pribadi yang disebut Personal Data Protection Commission and Administration (PDPCA). Lembaga khusus ini dibentuk oleh Menteri dengan total komisioner setidaknya tiga orang serta maksimal tujuh belas orang. Berdasarkan Pasal 6 PDPA, PDPCA mempunyai sejumlah fungsi antara lain:

1) mendorong kesadaran mengenai perlindungan data di Singapura; 
2) melakukan konsultasi, pendampingan hukum, administrasi, manajement, atau sejumlah pelayanan terkait dengan perlindungan data;

3) memberikan advice kepada pengambil kebijakan terhadap setiap problematika yang berhubungan dengan perlindungan data;

4) representasi Pemerintah di luar negeri yang berhubungan perlindungan data pribadi;

5) melaksanakan research dan education serta mendorong aktivitas pemahaman yang berhubungan dengan perlindungan data pribadi, serperti seminar, workshop dan lokakarya terkait dengan perlindungan data pribadi serta mengajak sejumlah lembaga lainnya untuk melaksanakan aktivitas-aktivitas tersebut;

6) mengatur technical cooperation serta saling berbagi informasi yang berhubungan dengan perlindungan data pribadi bersama lembaga atau organisasi lainnya, termasuk LSM, sebagia perwakilan dari pemerintah;

7) uphold dan menjalankan regulasi yang berkaitan dengan perlindungan data;

8) memberikan penegasan terkait fungsi atau kewenangan terhadap badan yang tercantum dalam regulasi lainnya; dan

9) terlibat dalam sejumlah aktivitas lainnya serta menjalankan tugasnya mewakili menteri atau untuk menunjuk komisi atas perintah dari gazette.

Terlihat meskipun tidak secara eksplisit menyebutkan independensi otoritas perlindungan data pribadi di Singapura, akan tetapi PDPCA mempunyai peran vital sebagai otoritas perlindungan data yang mandiri.

Selain PDPCA, dalam PDPA Singapura juga dikenal Advisory committees. Advisory committees adalah sebuah komisi advisor yang total anggotanya adalah (2)dua atau lebih serta appointed by menteri untuk memberikan advice kepada komisi yang berhubungan dengan tugas dan kewenangannya dalam regulasi". PDPCA mempunyai kesempatan untuk melakukan konsultasi kepada komisi advisor berkaitan dengan pelaksanaan dari fungsinya serta kewenangannya, dalam menjalankan kewenangannya komisi ini didasarkan pada undang-undang akan tetapi tidak mempunyai daya ikat, kedudukannya sebagaimana halnya konsultasi.

Sebagai checks and balances terhadap keputusan PDPCA, Pasal 48P PDPA Singapura juga mengenal komisi banding (appeal comittee), yaitu komisi banding yang dibentuk oleh Menteri untuk memberikan kesempatan bagi semua pihak yang keberatan terhadap keputusan PDPCA.

Berdasarkan komparasi terhadap kedua negara tersebut dapat dilihat bahwa antara Korea Selatan dan Singapura mempunyai karakteristik yang berbeda. Otoritas di Korea Selatan mempunyai kemandirian karena berada diluar kekuasaan eksekutif, legislatif dan yudikatif. Sementara itu PDPCA Singapura meskipun independen 
secara kelembagaan, akan tetapi komisionernya diangkat dan diberhentikan oleh Menteri. Hal ini menurut The Eurepean Commision View berpotensi untuk mengganggu independensi suatu lembaga. Akan tetapi, sebagai upaya untuk memastikan adanya checks and balances, dibentuklah komisi banding (appeal commission).

4. Desain Ideal Lembaga Otoritas Independen Perlindungan Data Pribadi dalam Sistem Ketatanegaraan Indonesia

Dalam konteks sistem ketatanegaraan Indonesia, varian lembaga negara yang dapat dibentuk menurut Zainal Arifin Mochtar ada dua yaitu lembaga negara independen atau lembaga negara eksekutif. Perbedaan tersebut terletak pada proses rekrutmen komisioner, independensi SDM hingga pengelolaan anggaran yang bersifat mandiri.

Mengacu pada sejumlah komparasi yang terdapat disejumlah negara yang telah dibahas pada sub-bab sebelumnya antara lain Singapura dan Korea Selatan, dapat dipahami terdapat beberapa model desain kelembagaan terkait perlindungan data pribadi, yaitu:

Pertama, dibentuk sebagai lembaga negara yang bersfat independen. Konsep ini diterapkan di Korea Selatan, dimana lembaga tersebut mempunyai kewenangan absolut terkait perlindungan data pribadi antara lain basic plan dan implementation plan, problematika terkait kebijakan yang lebih baik, sistem serta regulasi yang berkaitan dengan ptoteksi data, masalah koordinasi posisi yang ditempati institusi publik dalam hal pemrosesan data pribadi; dan masalah terkait pemahaman dan penegakan hukum serta peraturan terkait ptoteksi data pribadi. Selain itu, PIPC Korea Selatan juga mempunyai independensi tunggal, dalam artian PIPC tidak dapat diintervensi baik oleh kekuasaan eksekutif.

Kedua, digabung dengan lembaga negara lainnya. Konsep tersebut dapat dilakukan dengan membagi kewenangan terkait perlindungan data pribadi ke sejumlah lembaga negara yang saat ini telah terbentuk berdasarkan fungsi dan kewenangannya. Sebagai contoh hal ini dapat dilakukan dengan melakukan pengamatan terhadap sejumlah lembaga negara yang saat ini sudah ada dalam sistem ketatanegaraan Indonesia, antara lain:

(1) Pengaturan

(2) Pengawasan

(3) Perlindungan

(4) Penegakan Hukum

(5) Penyelesaian Konflik

Mengacu pada GDPR, pembentukan otoritas independen dapat dilakukan dilebih dari satu instansi. Dalam konteks sistem ketatanegaraan Indonesia, kondisi ini dapat ditindaklanjuti dengan memberikan kewenangan kepada sejumlah instansi terkait berdasarkan pada kewenangannya masing-masing. Akan tetapi menjadi pertanyaan terkait independensi lembaga negara yang pimpinan tertingginya diangkat serta diberhentikan oleh Presiden.

Ketiga, menjadi bagian dari kewenangan pemerintah sebagaimana yang terdapat dalam RUU Perlindungan Data Pribadi. Dalam konteks ini, 
perlindungan data pribadi pengelolaannya diatur secara keseluruhan oleh Pemerintah. Terkait pengawasan serta perlindungan tidak diatur secara spesifik. Konsep ini tidak ideal manakala merujuk pada sejumlah kesepakatan internasional terkait perlindungan data pribadi antara lain UN Guidelines for The Regulation of Computerized Personal Data Files 1990, Euorepean Modernized Convention for The Protection of Individual with Regard to The Processing of Personal Data 1981 (Convention 108), APEC Privacy Framework 2015, dan Euoropean Union General Data Protection Regulation (GDPR). Oleh karena itulah, opsi ketiga selayaknya tidak digunakan sebagai upaya pemenuhan perlindungan hak privasi dalam sistem ketatanegaraan Indonesia.

Sebagai perwujudan negara hukum yang tunduk pada konstitusi, RUU Perlindungan Data Pribadi selayaknya menempatkan warga negara sebagai prioritas. Berdasarkan sejumlah kesepatakan internasional, independensi suatu lembaga merupakan sesuatu yang urgen dalam perlindungan data pribadi. Oleh karena itulah, Undang-Undang Perlindungan Data Pribadi selayaknya menempatkan Otoritas Independen sebagai lembaga yang berwenang mutlak. Akan tetapi sebagai upaya memastikan tetap berjalannya check and balances, penulis mengusulkan dibentuknya Komisi Banding yang dibentuk secara independen untuk mengadili keputusan-keputusan Otoritas Perlindungan Data Pribadi.

Berdasarkan hal tersebutlah, penulis menawarkan pembentukan Otoritas Perlindungan Data Pribadi yang akan diberi nama Komisi Perlindungan Data Pribadi RI (Komperdadi RI) yang akan mempunyai sejumlah kewenangan antara lain:

a. Penyelenggaraan perlindungan data pribadi

b. Mengeluarkan kebijakan, sistem dan peraturan yang berkaitan dengan perlindungan data;

c. Sebagai koordinator terkait institusi publik serta privat dalam hal pemrosesan data pribadi; dan

d. Sebagai verifikator penegakan hukum terkait perlindungan data pribadi, dalam artian pelanggaran terkait PDP harus melalui Komperdadi terlebih dahulu sebelum diajukan gugatan ke Pengadilan untuk perkara perdata atau ke Kepolisian untuk perkara pidana;

Selain Komperdadi RI, penulis juga mengusulkan pembentukan Komisi Banding Perlindungan Data Pribadi yang disingkat Kombad PDP yang mempunyai fungsi untuk mengadili keberatan-keberatan yang muncul akibat keputusan Komperdadi. Akan tetapi, putusan Kombad RI bukanlah putusan pengadilan, sehingga dapat diajukan keberatan ke PTUN. Secara sederhana, desain sistem ketatanegaraan Indonesia terkait perlindungan data pribadi adalah sebagai berikut: 


\section{Gambar 1}

Desain Otoritas PDP dalam Sistem Ketatanegaraan Indonesia

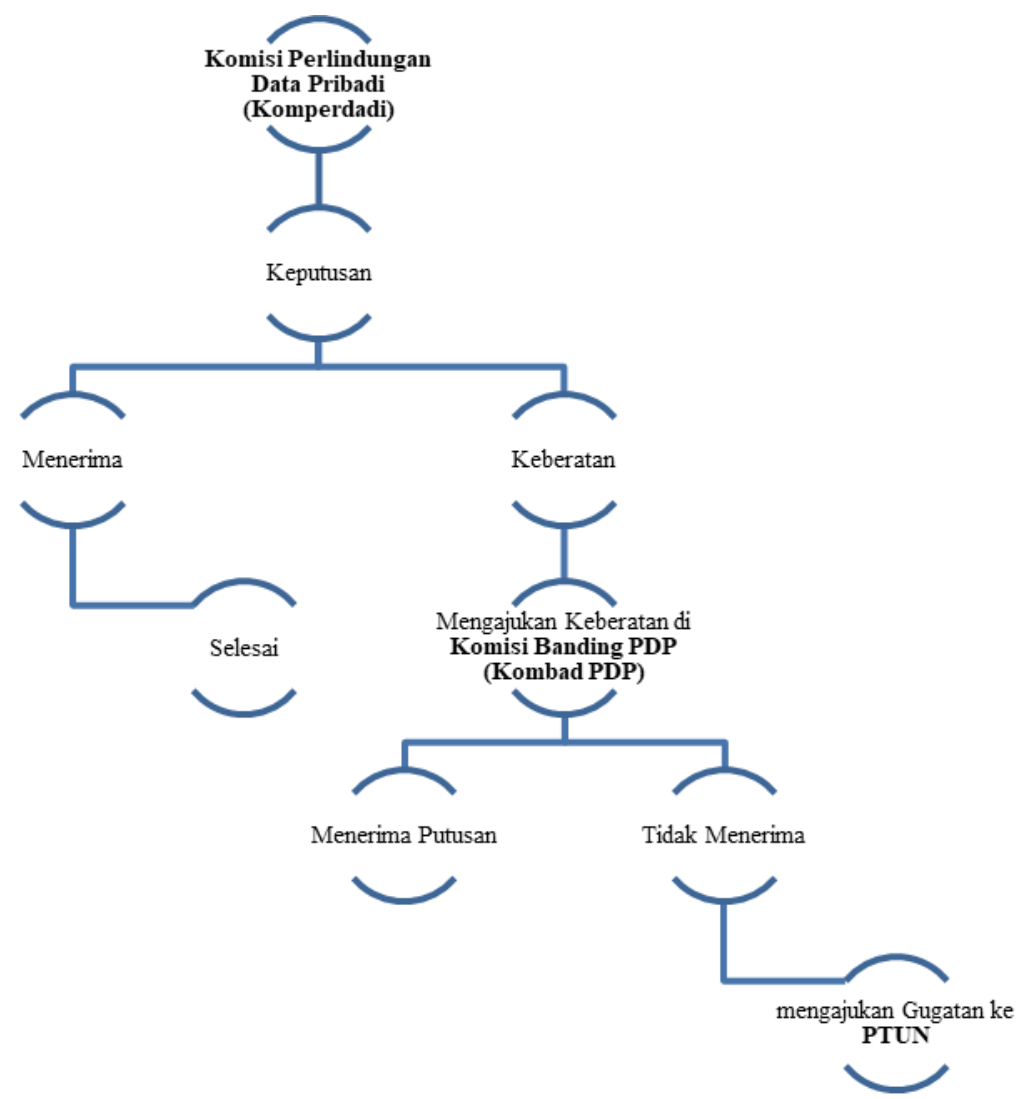

Terlihat berdasarkan gambar 1 , terdapat tiga lembaga yang berwenang menangani perlindungan data pribadi yaitu Komperdadi, Kombad PDP dan PTUN. Sebagai upaya menjaga independensi Komperdadi dan Kombad PDP, penulis mengusulkan pemilihan komisioner dilakukan berdasarkan usul Presiden dan DPR yang melakukan pemilihan. Usul Presiden harus $3 x$ jumlah calon yang dipilih, dalam artian apabila jumlah komisioner 5 (lima) orang, maka calon yang diusulkan Presiden haruslah 15 (lima belas) orang. Hal ini sebagai upaya untuk memastikan independensi Komperdadi dan Kombad PDP dalam sistem ketatanegaraan Indonesia.

\section{KESIMPULAN}

Pembentukan otoritas independen perlindungan data pribadi urgen untuk diterapkan di Indonesia. Mengacu pada APEC Policy Framework 2015 disebutkan bahwa pembentukan otoritas independen harus menyesuaikan dengan sistem ketatanegaraan masing-masing negara. Oleh karena itulah, artkel ini mencoba menawarkan desain ideal pembentukan otoritas independen dalam sistem ketatanegaraan Indonesia.

Sebagai perwujudan negara hukum yang tunduk pada konstitusi, RUU Perlindungan Data Pribadi selayaknya menempatkan warga negara sebagai prioritas. Berdasarkan sejumlah kesepatakan internasional, independensi suatu lembaga merupakan sesuatu yang urgen dalam 
perlindungan data pribadi. Oleh karena itulah, Undang-Undang Perlindungan Data Pribadi selayaknya menempatkan Otoritas Independen sebagai lembaga yang berwenang mutlak. Akan tetapi sebagai upaya memastikan tetap berjalannya check and balances, penulis mengusulkan dibentuknya Komisi Banding yang dibentuk secara independen untuk mengadili keputusan-keputusan Otoritas Perlindungan Data Pribadi.

Berdasarkan hal tersebutlah, penulis menawarkan pembentukan Otoritas Perlindungan Data Pribadi yang akan diberi nama Komisi Perlindungan Data Pribadi RI (Komperdadi RI) yang akan mempunyai sejumlah kewenangan antara lain: Penyelenggaraan perlindungan data pribadi, Mengeluarkan kebijakan, sistem dan peraturan yang berkaitan dengan perlindungan data;, Sebagai koordinator terkait institusi publik serta privat dalam hal pemrosesan data pribadi; dan Sebagai verifikator penegakan hukum terkait perlindungan data pribadi, dalam artian pelanggaran terkait PDP harus melalui Komperdadi terlebih dahulu sebelum diajukan gugatan ke Pengadilan untuk perkara perdata atau ke Kepolisian untuk perkara pidana;

Selain Komperdadi RI, penulis juga mengusulkan pembentukan Komisi Banding Perlindungan Data Pribadi yang disingkat Kombad PDP yang mempunyai fungsi untuk mengadili keberatan-keberatan yang muncul akibat keputusan Komperdadi. Akan tetapi, putusan Kombad RI bukanlah putusan pengadilan, sehingga dapat diajukan keberatan ke PTUN.

\section{Buku:}

\section{DAFTAR PUSTAKA}

Djafar, Wahyudi, and Asep Komarudin, 2014, Perlindungan Hak Atas Privasi Di Internet-Beberapa Penjelasan Kunci, Elsam, Jakarta;

Ibrahim, Johni, 2007, Teori Dan Metodologi Penelitian Hukum Normatif, Bayumedia Publishing, Malang;

Mochtar, Zainal Arifin, 2016, Lembaga Negara Independen: Dinamika Perkembangan Dan Urgensi Penataannya Kembali Pasca Amandemen Konstitusi, PT Raja Grafindo Persada, Jakarta;

\section{Jurnal:}

Anderson, Scott A, Privacy without the Right to Privacy, Monist, Vol.91, No. 1, 2008;

Diggelmann, Oliver, and Maria Nicole Cleis, How the Right to Privacy Became a Human Right, Human Rights Law Review, Vol.14, No.3, 2014;

Djanggih, Hardiyanto, and Yusuf Saefudin, De Jure De Jure, Jurnal Penelitian Hukum, Vol.17, No. 3, 2017;

European Union Agency for Fundamental Rights and Council of Europe. Handbook on European Data Protection Law, Belgium, 2014;

Finck, Michèle, and Frank Pallas, They Who Must Not Be IdentifiedDistinguishing Personal from Non-Personal Data under the GDPR, 
International Data Privacy Law, Vol.10, No.1, 2020;

Furqon, Eki, Kedudukan Lembaga Negara Independen Berfungsi Quasi Peradilan Dalam Sistem Ketatanegaraan Indonesia, Nurani Hukum, Vol.3, No.1, 2020;

Limba, Tadas, and Aurimas Šidlauskas, Secure Personal Data Administration in the Social Networks: The Case of Voluntary Sharing of Personal Data on the Facebook, Entrepreneurship and Sustainability Issues, Vol.5, No.3, 2018;

Muchda, Metia Winati, Maryati Bachtiar, and Dasrol, Pengalihan Tugas Pengaturan Dan Pengawasan Perbankan Dari Bank Indonesia Kepada Otoritas Jasa Keuangan Berdasarkan Undang-Undang Nomor 21 Tahun 2011 Tentang Otoritas Jasa Keuangan, JURNAL EKONOM, Vol.22, No.2, 2014;

Pfisterer, Valentin M, The Right to Privacy-a Fundamental Right in Search of Its Identity: Uncovering the CJEU's Flawed Concept of the Right to Privacy, German Law Journal, Vol.20, No.5, 2019;

Ramadani, Rizki, Lembaga Negara Independen Di Indonesia Dalam Perspektif Konsep Independent Regulatory Agencies, Jurnal Hukum Ius Quia Iustum, Vol.27, No.1, 2020;

Suparto, Pemisahan Kekuasaan, Konstitusi Dan Kekuasaan Kehakiman Yang Independen Menurut Islam, Jurnal Selat, Vol.4, No.1, 2016;

Tyler, Michele L, Blowing Smoke: Do Smokers Have a Right? Limiting the Privacy Rights of Cigarette Smokers, Georgetown Law Journal, Vol.86, No.3, 1998;

Yuniarti, Siti, Perlindungan Hukum Data Pribadi Di Indonesia, Business Economic, Communication, and Social Sciences (BECOSS) Journal 1, No.1, 2019; 